ISSN 1392-3196 / e-ISSN 2335-8947

Zemdirbyste-Agriculture, vol. 108, No. 1 (2021), p. 79-86

DOI 10.13080/z-a.2021.108.011

\title{
Nitrogen and chlorophyll status in romaine lettuce using spectral indices from RGB digital images
}

\author{
Rodrigo Omar MENDOZA-TAFOLLA ${ }^{1}$, Ronald Ernesto ONTIVEROS-CAPURATA ${ }^{2}$, \\ Porfirio JUAREZ-LOPEZ ${ }^{1}$, Iran ALIA-TEJACAL ${ }^{1}$, Victor LOPEZ-MARTINEZ ${ }^{1}$, \\ Osias RUIZ-ALVAREZ ${ }^{3}$ \\ ${ }^{1}$ Autonomous University of the State of Morelos, Faculty of Agricultural Sciences \\ Avenida Universidad 1001, 62210 Cuernavaca, Morelos, Mexico \\ ${ }^{2}$ Mexican Institute of Water Technology, National Council of Science and Technology (CONACYT) \\ Paseo Cuauhnáhuac 8532, 62550 Jiutepec, Morelos, Mexico \\ E-mail: reontiverosca@conacyt.mx \\ ${ }^{3}$ National Remote Sensing and Modeling Laboratory (LNMySR), \\ National Institute of Agricultural and Livestock Forest Research (INIFAP) \\ Km. 32.5 Carretera Aguascalientes - Zacatecas, 20670, Pabellon de Arteaga, Aguascalientes, Mexico
}

\begin{abstract}
Destructive methods for crop nutrition estimation are accurate and standardized but costly and limited by spatial scale. Non-destructive techniques such as the use of digital imaging provide fast and reliable results in situ; however, there is limited information on these non-destructive techniques in leafy vegetable crops. During the study it was estimated the concentration of nitrogen $(\mathrm{N})$ and chlorophyll $(\mathrm{Chl})$ in romaine lettuce using spectral indices derived from the RGB (red, green and blue) digital images. The lettuce crop was grown in plastic tunnels and irrigated with five $\mathrm{N}$ levels: $0,4,8,12$, and $16 \mathrm{mEq} \mathrm{L}^{-1} \mathrm{NO}_{3}-\mathrm{N}$ (corresponding to $0,248,496$ and $744 \mathrm{mg} \mathrm{L}^{-1}$, respectively) based on a modified Steiner solution. The treatment of $16 \mathrm{mEq} \mathrm{L}-1 \mathrm{NO}_{3}-\mathrm{N}$ showed the highest growth at 42 days after transplanting (DAT). Digital images of the plants were acquired weekly with a RGB camera and processed to obtain scale mosaics and twelve spectral vegetation indices. Correlation analysis of the spectral indices indicated that normalized green-red difference index (NGRDI), excess green (ExG) and green channel $(g)$ indices showed a positive linear correlation with the concentration of $\mathrm{N}(r>0.93)$ and $\mathrm{Chl}(r>0.93)$. Besides, an exponential correlation with leaf area $(r>0.86)$ was founded, which was stronger in the last 21 DAT due to the acceleration in leaf growth during the vegetative stage of the crop. These results show that RGB digital images are a low cost, non-destructive, reliable and accurate method to estimate $\mathrm{N}$ and $\mathrm{Chl}$ concentration and leaf area in romaine lettuce during production. Therefore, this technique could be an affordable alternative that combined with portable meters (i.e. SPAD) provides real-time monitoring of the nutritional status of the lettuce crop, especially in crop factories.
\end{abstract}

Key words: Lactuca sativa var. longifolia, leaf area, non-destructive techniques, nitrogen, chlorophyll, spectral index.

\section{Introduction}

Chlorophyll (Chl) and nitrogen $(\mathrm{N})$ are essential components of plants because of their role in protein production and photosynthesis. An excess or deficiency of these can cause toxicity or low yield (Taiz et al., 2014). Precise assessment and evaluation of the nutritional status of the crop in situ and at different time scales is required to optimize the use of fertilizers and reduce costs (Muñoz-Huerta et al., 2013).

Nitrogen concentration in plants is usually determined by two approaches - the destructive or non-destructive methods. Destructive methods such

as Kjeldahl and Dumas are based on tissue analysis and although they are accurate and standardized, they are often limited by the size of the plots, high cost and efforts required for sampling (Paz Pellat et al., 2015; Baresel et al., 2017). Non-destructive methods allow for remote information collection in less time and do not require highly specialized personnel (Vollmann et al., 2011). Besides, measurements may be applied frequently and repeatedly on the same plant; thus allowing the monitoring of leaf area and crop $\mathrm{N}$ status for efficiently adjusting fertilization rates throughout the growing 
season (Sandmann et al., 2013). These methods use the relationship of reflectance / transmittance properties of some leaf pigments such as $\mathrm{Chl}$ and polyphenols with their chemical characteristics (Parks et al., 2012).

It is well known that changes in plant spectral characteristics are closely related to changes in nutrient concentration in the visible $(\sim 550 \mathrm{~nm})$ and near-infrared $(\sim 750 \mathrm{~nm})$ regions (Muñoz-Huerta et al., 2013). If they are combined as spectral indices, it is possible to obtain functional relations that estimate the concentration of $\mathrm{N}$ and Chl (Cammarano et al., 2014). Remote sensing data of crops are acquired at leaf level from Chl meters (e.g., SPAD) or at canopy level from reflectance sensors (e.g., digital cameras). In the first case, the approach is the point sampling with a limited spatial scale, while in the second, it allows monitoring of spatial and temporal variability (Muñoz-Huerta et al., 2013).

Using digital cameras and image processing (e.g., visible spectral indices) is less expensive than other techniques (Elsayed et al., 2018) and have been reported to be a powerful and low-cost tool in assessing leaf area and nutrient status, especially in field crops (Liu et al., 2018; Prey et al., 2018; Zheng et al., 2018). In horticulture, the processing images have been used to estimate the $\mathrm{N}$ and Chl concentration in tomato (Mercado-Luna et al., 2010), potato (Yadav et al., 2010), pepper (Yuzhu, 2011) and sweet pepper (Horgan et al., 2015) seedlings, but there are few studies in leafy vegetables (Jung et al., 2015; Mao et al., 2015).

The advantages of using non-destructive optical methods have been widely studied in field crops (Elsayed et al., 2018). Furthermore, although studies in closed environment systems are few, they show promising results that have allowed, according to Jung et al. (2015), quick and successful estimation of the $\mathrm{N}$ and Chl concentration in lettuce. Therefore, these methods could be incorporated into high-tech closed production systems for the measurement of nutritional status in less time, allowing the necessary adjustments in fertilization schemes to optimize resources, reduction in production costs and increase in yields (Gruda et al., 2019). In the countries such as Mexico, lettuce production in greenhouses is a continuously growing area that could benefit from a precise diagnosis and monitoring system of the nutritional status of $\mathrm{N}$ with high spatio-temporal precision, considering that $\mathrm{N}$ is the most limiting nutrient to the yield (Zhou et al., 2020).

This paper explores the possibility of estimating the $\mathrm{N}$ and $\mathrm{Chl}$ concentration and leaf area of romaine lettuce using a non-destructive method based on digital images from a visible RGB camera and spectral indices. It could be used as a practical and low-cost alternative to traditional destructive methods and providing accurate information with higher spatial resolution than measurements with proximal sensors such as SPAD, which could be useful for application in the greenhouse vegetable production industry.

\section{Materials and methods}

Cultural conditions and crop management. This experiment was conducted from April to May of 2018 in high tunnels, at the Faculty of the Agricultural Sciences $\left(18^{\circ} 58^{\prime} 51^{\prime \prime} \mathrm{N}, 99^{\circ} 13^{\prime} 745^{\prime \prime} \mathrm{W}\right.$, alt. $\left.1,866 \mathrm{~m}\right)$ in the Autonomous University of the State of Morelos, Mexico. Air temperature, relative humidity and light intensity were recorded every 5 minutes with a Hobo ${ }^{\circledR}$ datalogger
U12-012 (Onset Computer Co., USA) throughout the experiment. The average values of temperature, relative humidity and light intensity were $26^{\circ} \mathrm{C}, 45 \%$ and $518 \mu \mathrm{mol} \mathrm{m}^{-2} \mathrm{~s}^{-1}$, respectively.

Romaine lettuce (Lactuca sativa var. longifolia) cultivar 'Green Star' (Johnny's Seeds, USA) was sown on 13 March 2018, in 200-cavity polystyrene trays with commercial BM2 Berger ${ }^{\circledR}$ substrate. After 30 days, lettuce seedlings were transplanted into $10 \mathrm{~L}$ polyethylene bags containing volcanic rock (locally called tezontle, with 1 to $7 \mathrm{~mm}$ grain size) as substrate. The plants were watered daily with $0.5 \mathrm{~L}$ (first 21 days) and $1.5 \mathrm{~L}$ (last 21 days) of a Steiner (1984) nutrient solution, modified to supply five nitrate nitrogen $(\mathrm{N})$ levels: $0,4,8,12$ and $16 \mathrm{mEq} \mathrm{L}{ }^{-1} \mathrm{NO}_{3}-\mathrm{N}$ (corresponding to 0, 248, 496, 744 and $992 \mathrm{mg} \mathrm{L}^{-1} \mathrm{NO}_{3}-\mathrm{N}$, respectively), as recommended by Mercado-Luna et al. (2010). The chemical composition of the original Steiner nutrient solution was: 1.062 $\mathrm{Ca}\left(\mathrm{NO}_{3}\right)_{2}$ (calcium nitrate), $303 \mathrm{KNO}_{3}$ (potassium nitrate), $492 \mathrm{MgSO}_{4}$ (magnesium sulphate), $261 \mathrm{~K}_{2} \mathrm{SO}_{4}$ (potassium sulphate) and $136 \mathrm{KH}_{2} \mathrm{PO}_{4}$ (monopotassium phosphate), in $\mathrm{mg} \mathrm{L}^{-1}$. Macronutrients were supplied from soluble fertilizers depending on the treatments. When necessary, calcium sulphate $\left(272.3 \mathrm{mg} \mathrm{L}^{-1} \mathrm{CaSO}_{4}\right)$ and calcium chloride (55.5 mg L-1 $\mathrm{CaCl}_{2}$ ) were added to maintain a balance of $20 \mathrm{mEq} \mathrm{L} \mathrm{L}^{-1}$ anions-cations in the nutrient solutions. The micronutrients were applied through a commercial chelate mixture Ultrasol Micro Mix (SQM, Chile), in a dose of $80 \mathrm{~g} \mathrm{~m}^{-3}$ of nutrient solution. To calculate that dose, the supply of $3 \mathrm{mg} \mathrm{L}^{-1} \mathrm{Fe}$ was considered. The commercial mixture of micronutrients contained the following concentrations in percentage: $\mathrm{Fe}$ (7.5), Mn (3.7), B (0.4), Zn (0.6), Cu (0.3) and Mo $(0.2)$. After preparing the nutrient solutions, the $\mathrm{pH}$ was adjusted between 5.6 and 6.0 with $\mathrm{H}_{2} \mathrm{SO}_{4}$ (sulfuric acid). Plants were watered to provide a $15 \%$ to $20 \%$ leachate fraction to prevent salt accumulation.

Experimental design and reference data. A completely randomized experimental design with 180 pots in total (36 pots per treatment) distributed in five $\mathrm{N}$ treatments: $0,4,8,12$ and $16 \mathrm{mEq} \mathrm{L} \mathrm{L}^{-1} \mathrm{NO}_{3}-\mathrm{N}$, was used. Sampling was done weekly from 7 to 42 days after transplantation (DAT), for analysis, 6 pots of each treatment with one plant per pot as the experimental unit were used. The leaf area of each plant in $\mathrm{cm}^{2}$ was measured with a portable area meter LI-3100 (LI-COR Biosciences, USA). Chlorophyll concentration ( $\left.\mathrm{mg} \mathrm{g}^{-1}\right)$ was estimated from the 18 recently matured (fully expanded) leaves by treatment (3 leaves per plant) with the spectrophotometric method described by Mackinney (1941) and Wettstein (1957). Leaves used to measure leaf area were dried in a forced-air oven at $70{ }^{\circ} \mathrm{C}$ temperature for $72 \mathrm{~h}$ and used to determine the total $\mathrm{N}$ by the micro-Kjeldahl method (Kalra, 1997).

Image acquisition and processing. Coded targets were placed as ground control points (GCPs) at a distance of 45 by $45 \mathrm{~cm}$. The digital images were acquired using RGB camera WB250F $16 \mathrm{Mpx}$ (Samsung) mounted on a goniometer (Sandmeier, 2000) in an inclination range of $15^{\circ}$ to $165^{\circ}$ every $25^{\circ}$, taking at least 50 pictures in each session with a minimum $70 \%$ overlap. A photogrammetric restitution process using software Agisoft Photoscan, version 1.2 (Agisoft LLC, Russia) was performed according to Grenzdörffer (2014) to generate scaled ortho-mosaics and three-dimensional digital models (Fig. 1). 


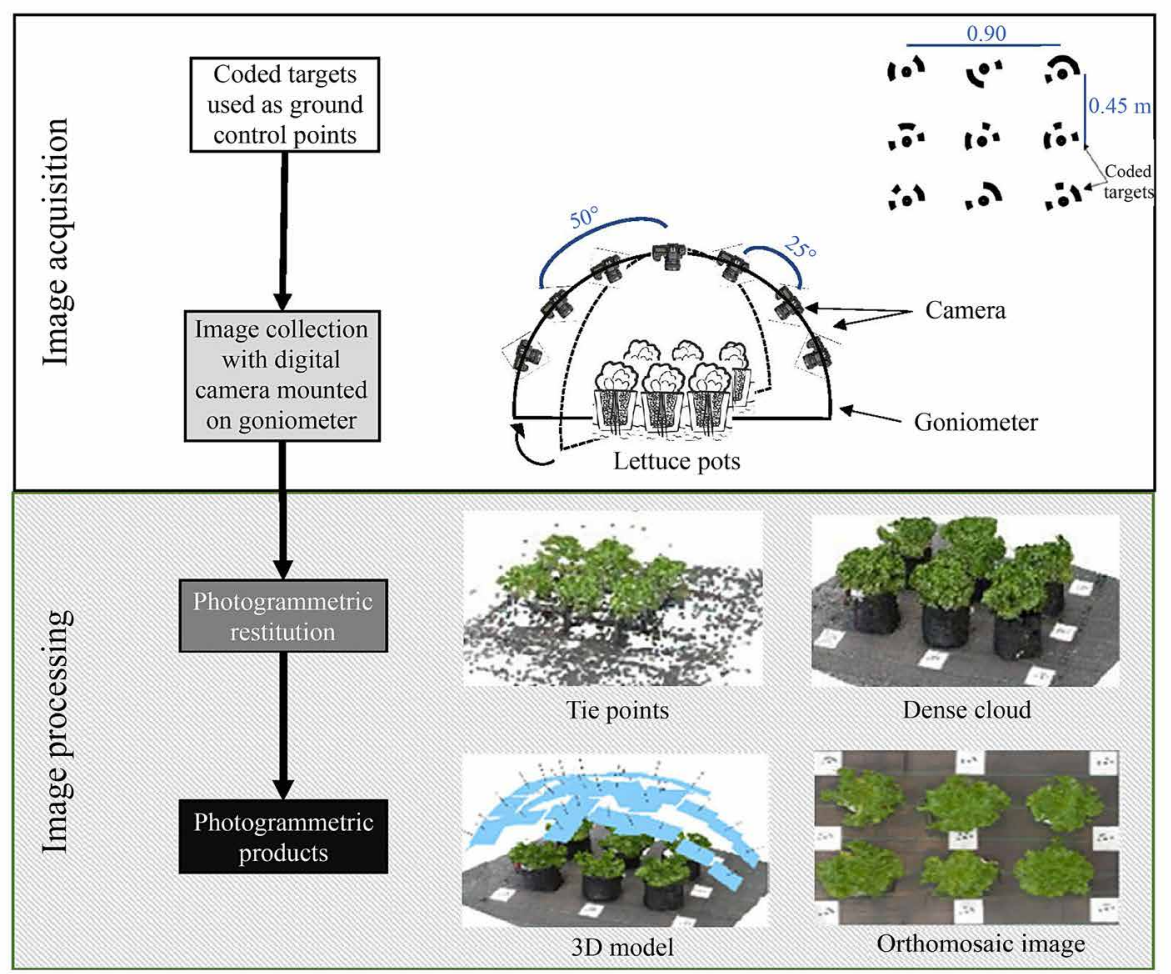

Figure 1. The process to generate scaled orthomosaic images and 3D models

Spectral indices calculation and classification images. Twelve spectral vegetation indices based on the three RGB (red, green and blue) visible region bands (Table 1) were calculated from the orthomosaics through a script in the statistical software $R$, version 3.5.0 (R Core Team, 2019).
Each spectral vegetation index image was subjected to a supervised classification process using the maximum likelihood method to separate the pixels corresponding to the lettuce crop, obtaining images classified with three classes: leaf area, substrate and soil. The pixel values of the lettuce crop in the classified

Table 1. Spectral indices calculated from the RGB (red, green and blue) digital images

\begin{tabular}{|c|c|c|c|}
\hline Index name & Application & Equation & References \\
\hline $\begin{array}{l}\text { 1. Normalized green-red difference index } \\
\text { (NGRDI) }\end{array}$ & biomass, N, phenology & $(G-R) /(G+R)$ & Jannoura et al., 2015 \\
\hline 2. Normalized difference index (NDI) & $\mathrm{N}, \mathrm{Chl}$ & $(R-G) /(R+G+0.01)$ & \\
\hline 3. Intensity (INT) & & $(R+G+\mathrm{B}) / 3$ & Lee, Lee, 2013 \\
\hline 4. Saturation (SAT) & colour, canopy & $1-(3 \times \mathrm{R} \times \mathrm{G} \times \mathrm{B})$ & \\
\hline 5. Excess green index $(\mathrm{ExG})$ & segmentation, Chl, $\mathrm{N}$ & $((2 \times G)-(R+B)) /(R+G+B)$ & \multirow{7}{*}{ Baresel et al., 2017} \\
\hline 6. Channel index R $(r)$ & \multirow{6}{*}{ greenness, Chl, N } & $R /(R+G+B)$ & \\
\hline 7. Channel index G ( $g$ ) & & $G /(R+G+B)$ & \\
\hline 8. Channel index B $(b)$ & & $B /(R+G+B)$ & \\
\hline 9. Binary channel index $(r b)$ & & $\mathrm{R} / \mathrm{B}$ & \\
\hline 10. Binary channel index $(r g)$ & & $\mathrm{R} / \mathrm{G}$ & \\
\hline 11. Binary channel index (bg) & & $\mathrm{B} / \mathrm{G}$ & \\
\hline 12. Triangular green index (TGI) & Chl & $G-(0.39 \times R)-(0.61 \times B)$ & Hunt et al., 2013 \\
\hline
\end{tabular}

Spectral band regions: R - red, 650-700 nm, G - green, 500-550 nm, B - blue, 450-500 nm

images were compared with the reference data $(\mathrm{N}, \mathrm{Chl}$ and leaf area) using a simple correlation coefficients matrix, as reported by Chung et al. (2017). Therefore, those spectral indices that are statistically different and have the highest coefficient of correlation $(r)$ and the lowest root-mean-square error (RMSE) were identified and selected (Fig. 2).

Statistical analysis. Analysis of variance and Tukey's test for pairwise comparison was performed using the statistical software $S A S$, version 9.1 (SAS Institute, USA) with a one-way factor (N level) and statistical significance at $P \leq 0.01$. Arithmetic mean $(\overline{\mathrm{x}})$, standard error (SE), coefficient of variation (CV) and the least significant difference (LSD) were calculated. The simple linear regression model in the statistical software SigmaPlot, version 12 (SyStat Software Inc., USA) was used to assess the correlation between spectral indices and reference data values.

\section{Results and discussion}

Crop response to nitrogen $(N)$ levels. At $42 \mathrm{DAT}$, the treatment of $16 \mathrm{mEq} \mathrm{L}{ }^{-1} \mathrm{NO}_{3}-\mathrm{N}$ had the maximum values (statistically significant difference) of $\mathrm{Chl}, \mathrm{N}$ concentration and leaf area compared to the rest of the treatments (Table 2). 


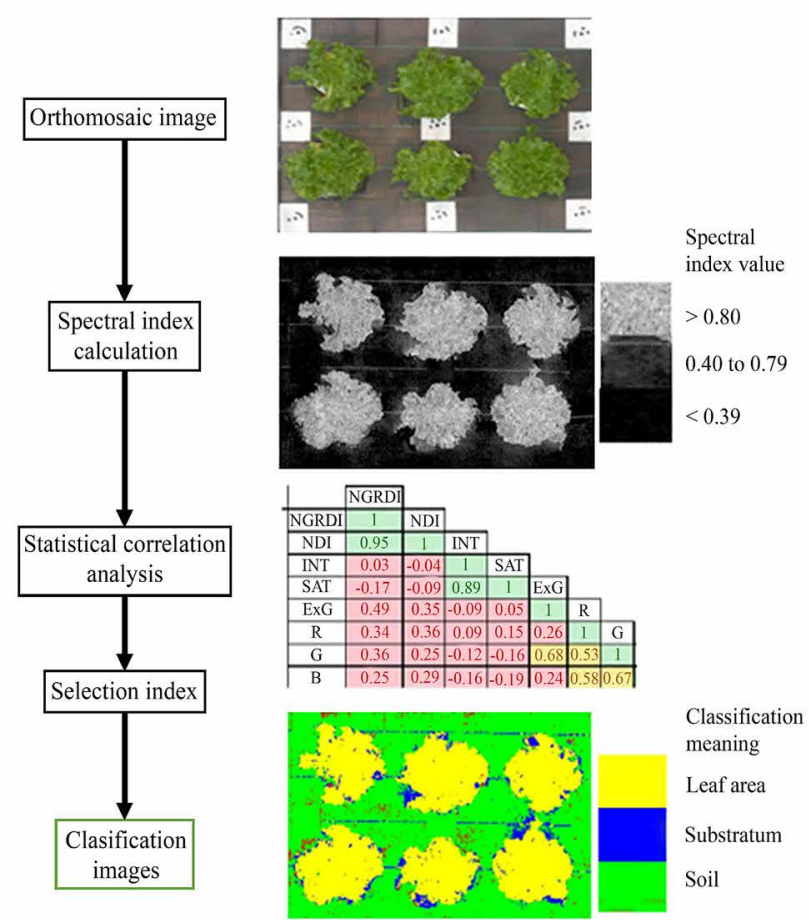

Figure 2. The process for spectral analysis of scaled orthomosaic images

Table 2. Response to different $\mathrm{NO}_{3}-\mathrm{N}$ levels at 42 days after transplanting (DAT) in romaine lettuce

\begin{tabular}{|c|c|c|c|}
\hline \multirow{2}{*}{$\begin{array}{l}\text { Treatment } \\
\text { mEq L-1 } \\
\mathrm{NO}_{3}-\mathrm{N}\end{array}$} & \multicolumn{3}{|c|}{$\overline{\mathrm{X}}$} \\
\hline & $\begin{array}{c}\mathrm{Chl} \\
\mathrm{mg} \mathrm{g}^{-1} \mathrm{FW}\end{array}$ & $\begin{array}{c}\mathrm{N} \\
\% \mathrm{DW}\end{array}$ & $\begin{array}{c}\text { leaf area } \\
\mathrm{cm}^{2}\end{array}$ \\
\hline 0 & $0.387 \mathrm{~b}$ & $2.48 \mathrm{~b}$ & $49.3 \mathrm{~d}$ \\
\hline 4 & $0.396 \mathrm{~b}$ & $2.51 \mathrm{~b}$ & $51.0 \mathrm{~cd}$ \\
\hline 8 & $0.402 \mathrm{~b}$ & $2.54 \mathrm{~b}$ & $53.9 \mathrm{c}$ \\
\hline 12 & $0.411 \mathrm{~b}$ & $2.75 \mathrm{~b}$ & $65.6 \mathrm{~b}$ \\
\hline 16 & $0.453 \mathrm{a}$ & $3.76 \mathrm{a}$ & $73.1 \mathrm{a}$ \\
\hline $\mathrm{CV}$ & 0.067 & 0.085 & 0.070 \\
\hline LSD & 0.038 & 0.906 & 4.437 \\
\hline
\end{tabular}

Note. FW - fresh weight, DW - dry weight; letters between columns indicate statistical difference $(P \leq 0.01)$.
There was a positive relationship between the $\mathrm{N}$ concentration of the nutrient solution and the $\mathrm{N}$ concentration in the plant tissue. This trend was reported by Zandvakili et al. (2019) in four cultivars of lettuce and by Fallovo et al. (2009) in lettuce 'Green Salad Bowl' crop. Similarly, there was a positive relationship between the concentration of $\mathrm{N}$ applied versus the concentration of $\mathrm{Chl}$ and leaf area. These same trends were reported for $\mathrm{Chl}$ in lettuce 'Parris Island' (Konstantopoulou et al., 2012). Nitrogen is the most important nutrient for leafy vegetables, especially at the end of the vegetative stage, which in lettuce coincides with its harvest. As a yield component of crop lettuce, leaf area was also positively influenced by the concentration of $\mathrm{N}$ in the nutrient solution. Besides, similar results have been reported in rocket salad (Eruca vesicaria L.) by Santamaria et al. (2002).

Correlation analysis between spectral indices values and reference data. The comparison between indices showed that NGRDI, NDI and TGI have a strong correlation between them, likewise INT and SAT. In our study, a moderate correlation $(r<0.74)$ between NGRDI with R, G and B was found, and these results agree with those obtained in tomato by Ali et al. (2013), who had correlation coefficients between 0.48 and 0.59 . The rest of the spectral indices had none or weak correlation between themselves (Table 3 ).

Strong and significant correlations $(r>0.80)$ were found between NGRDI, NDI, ExG and $g$ indices and reference data ( $\mathrm{N}, \mathrm{Chl}$ and LA). These indices were developed initially to detect the green parts of the plants, so they are known as greenness indices. Later on, given their ability to highlight the spectral characteristics of the green and red bands, they were used as an indicator of the quantity and quality of the photosynthetic material of the plants (Rasmussen et al., 2016), so in leafy vegetables such as lettuce could be an indicator of Chl, leaf area and biomass. In lettuce crop, Jung et al. (2015) reported that the $g$ index had the highest correlation for leaf area estimation $(r=0.93)$. The results of our experiment are similar to those reported by Xue and Yang (2008), where NGRDI and NDI could be used for the calculation of N concentration in the vegetative stage of rice $(r=0.95)$. It allows using these indices for the estimation of leaf area

Table 3. Correlation matrix between spectral indices and reference data values

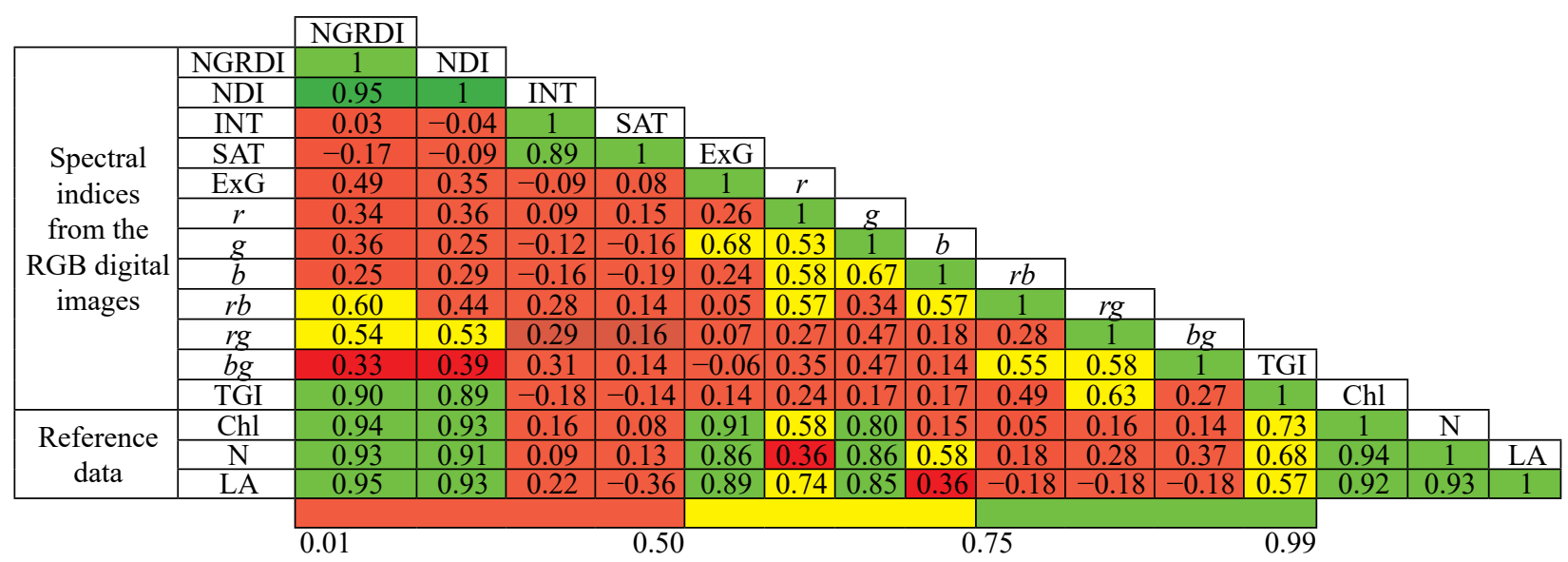

Note. Explanation of acronyms in Table 1; significant values are those marked with green colour $(P \leq 0.01)$.

accurately and quickly similar to reported in horticultural crops by Usha and Singh (2013).

The TGI index showed a moderate and significant correlation $(r>0.60)$ with $\mathrm{Chl}$ and $\mathrm{N}$. In contrast, the INT, SAT, $r, b, r b, b g$ and $r g$ indices produced a weak to moderate non-significant correlation $(r<0.60)$ with reference data.

In summary, it was found that the most efficient spectral indices are those that consider the spectral bands of the green and red region. On the other hand, the ExG 
and $g$ indices that incorporate the blue band have lower performance in the prediction of Chl, $\mathrm{N}$ and leaf area, which may be due to the low sensitivity of plant tissue in the blue channel $(\sim 450 \mathrm{~nm})$.

Comparison between reference data and spectral indices from RGB digital images. Chlorophyll concentration. The Chl values were compared for the two periods: (1) the whole crop cycle from 1 to 42 DAT and (2) from 22 to 42 DAT (Table 4). For the entire cycle, NGRDI $(r=0.94)$ and $g(r=0.86)$ indices had a strong linear correlation (Fig. 3).

Table 4. Linear regression coefficients and standard error (SE) for the relationship between the chlorophyll (Chl) concentration and spectral indices

\begin{tabular}{ccccc}
\hline \multirow{2}{*}{$\begin{array}{c}\text { Period } \\
\text { evaluated }\end{array}$} & \multirow{2}{*}{$\begin{array}{c}\text { Spectral } \\
\text { index }\end{array}$} & \multicolumn{2}{c}{$\begin{array}{c}\text { Linear regression } \\
\text { coefficient }\end{array}$} & \multirow{2}{*}{ SE } \\
\cline { 3 - 4 } & & $\mathrm{a}$ & $\mathrm{b}$ & \\
\hline 1 to 42 & $\mathrm{NGRI}^{* *}$ & 0.1052 & 1.3601 & 0.07 \\
DAT & $\mathrm{NuG}^{* *}$ & 0.1054 & 0.8673 & 0.08 \\
& $g^{* *}$ & 0.1133 & 2.1406 & 0.06 \\
\hline 22 to 42 & $\mathrm{NGRDI}^{* *}$ & 1.4536 & 0.1804 & 0.06 \\
DAT & $\mathrm{ExG}^{* *}$ & 1.4524 & 0.6623 & 0.07 \\
& $g^{* *}$ & 1.0622 & 0.2043 & 0.05 \\
\hline
\end{tabular}

Explanation of acronyms in Table 1; ** - high significant correlation between the variables $(P \leq 0.01)$

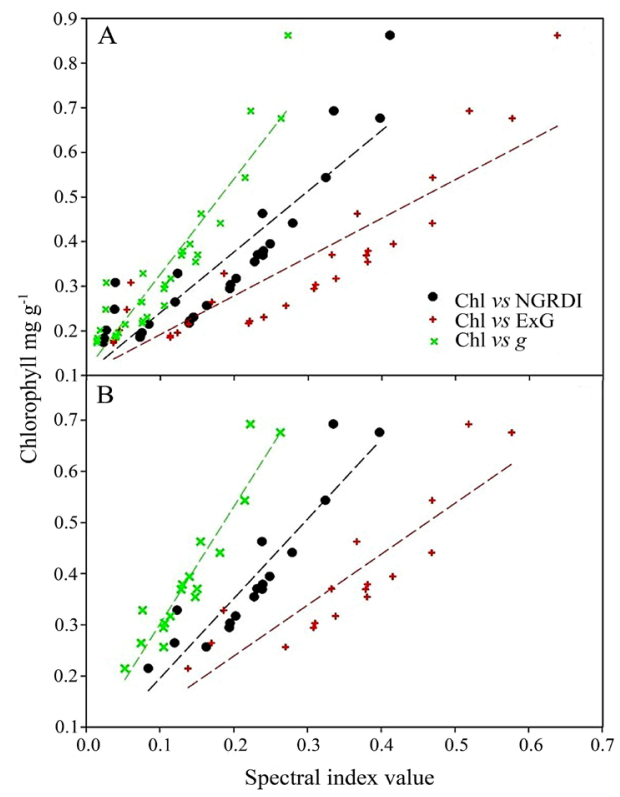

Explanation of acronyms in Table 1

Figure 3. Correlation between the chlorophyll (Chl) concentration and spectral indices (NGRDI, ExG and $g$ ) at 42 DAT (A) and the last 21 DAT (B)

These results are similar to those obtained by Álvarez-Bermejo et al. (2017) in tomato and cucumber using the NGRDI $(r=0.90)$, and De la Cruz et al. (2011) in wheat using the $g$ index $(r=0.97)$. Besides, there is a strong linear correlation with the ExG index $(r=0.88$, RMSE $=0.03)$, a value comparable to that reported by Elazab et al. (2016) in wheat $(r>0.93)$. On the other hand, Lin et al. (2013) obtained correlation coefficients of 0.85 between ExG and $\mathrm{Chl}$ concentration in cucumber plants during their vegetative stage.

A greater adjustment to the linear regression model was obtained if the values from 22 to 42 DAT are considered (Fig. 3). The index that presented the highest correlation was ExG $(r=0.92, \mathrm{RMSE}=0.03)$ compared to NGRDI $(r=0.93$, RMSE $=0.04)$ and $g(r=0.93$, RMSE $=0.02)$. Similar results were obtained by Sun et al. (2016), who recorded strong correlations $(r \geq 0.88)$ between ExG index and $\mathrm{Chl}$ concentration in cucumber. In this sense, Baresel et al. (2017) suggest that NGRDI and $\mathrm{ExG}$ indices can determine the $\mathrm{Chl}$ concentration in crops, because when using the $g$ band (500 to $550 \mathrm{~nm}$ ) it highlights the pigments responsible for the green colour of plants such as Chl allowing its quantification. On the other hand, Hunt et al. (2013) found that the relationship between NGRDI and Chl is not well established for all stages of the crop but could be more pronounced in early stages due to the existence of an underlying correlation with leaf area.

Nitrogen $(N)$ concentration. Table 5 shows the correlation analysis and regression coefficients between $\mathrm{N}$ concentration and spectral indices values.

Table 5. Linear regression coefficients for the relationship between the nitrogen $(\mathrm{N})$ concentration and spectral indices

\begin{tabular}{ccccc}
\hline \multirow{2}{*}{$\begin{array}{c}\text { Period } \\
\text { evaluated }\end{array}$} & \multirow{2}{*}{$\begin{array}{c}\text { Spectral } \\
\text { index }\end{array}$} & \multicolumn{2}{c}{$\begin{array}{c}\text { Linear regression } \\
\text { coefficient }\end{array}$} & \multirow{2}{*}{ SE } \\
\cline { 3 - 4 } & & $\mathrm{a}$ & $\mathrm{b}$ & \\
\hline 1 to 42 & $\mathrm{NGRDI}^{* *}$ & 7.9238 & 1.8789 & \multirow{2}{*}{0.06} \\
DAT & $\mathrm{ExG}^{* *}$ & 5.1094 & 1.8646 & 0.07 \\
& $\mathrm{~g}^{* *}$ & 12.2480 & 0.1133 & 0.07 \\
\multirow{2}{*}{22 to 42} & $\mathrm{NGRDI**}^{* *}$ & 3.6735 & 1.5245 & 0.08 \\
DAT & $\mathrm{ExG}^{* *}$ & 2.3247 & 1.9866 & 0.06 \\
& $g^{* *}$ & 6.6737 & 0.1535 & 0.05 \\
\hline
\end{tabular}

Explanation of acronyms in Table $1 ; * *$ - high significant correlation between the variables $(P \leq 0.01)$

The concentration values of $\mathrm{N}$ had a high linear correlation with the NGRDI $(r=0.95, \mathrm{RMSE}=0.06)$, $\mathrm{ExG}(r=0.94$, RMSE $=0.04)$ and $g$ index $(r=0.96$, RMSE $=0.04$ ) throughout the 42 DAT (Fig. 4).

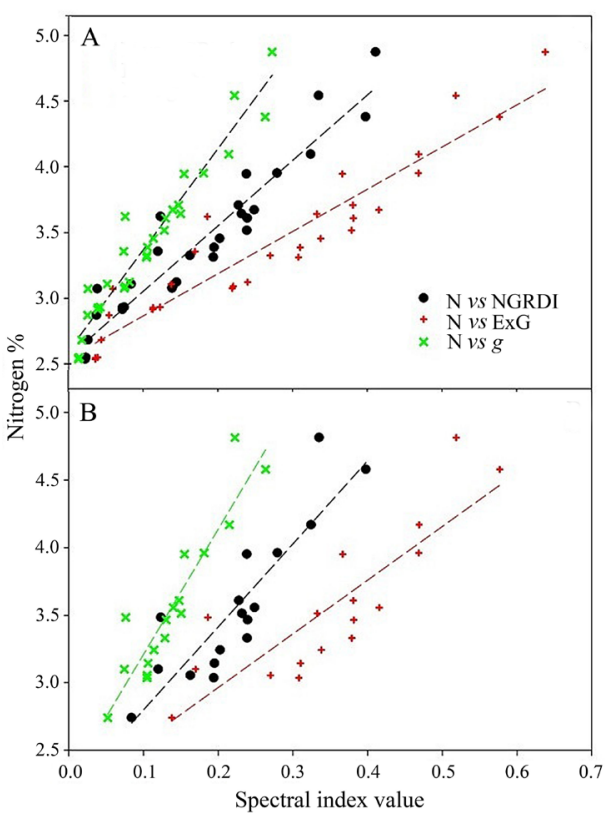

Explanation of acronyms in Table 1

Figure 4. Correlation between the nitrogen (N) concentration and spectral indices (NGRDI, ExG and $g$ ) at 42 DAT (A) and the last 21 DAT (B) 
During the vegetative stage of crop lettuce (last 21 DAT of the crop cycle), the relationship between the concentration of $\mathrm{N}$ and the NGRDI $(r=0.97, \mathrm{RMSE}=$ $0.05), \operatorname{ExG}(r=0.97, \mathrm{RMSE}=0.04)$ and $g(r=0.97, \mathrm{RMSE}$ $=0.06)$ showed greater adjustment to the linear regression model (Fig. 4). These results agree with those obtained by Meyer and Neto (2008), who reported coefficients of correlation $\geq 0.85$ for the ExG index in the quantification of $\mathrm{N}$ in stages of vegetative growth in soybean.

Few studies use the NGRDI to determine the concentration of $\mathrm{N}$ in vegetables; however, the use of this spectral index has shown strong correlation $(\geq 0.84)$ in the vegetative stage of maize (Hunt et al., 2013; Elazab et al., 2016), rice (Zheng et al., 2018) and wheat (Yang et al., 2020). Besides, spectral indices of the RGB visible region were shown to be efficient in determining $\mathrm{N}$ concentration in bean plants due to their effect on the amount and colouration of pigments within plant tissues (Lee, Lee, 2013), which indicates that the use of spectral indices represents a reliable and accurate methodology for quantifying the concentration of $\mathrm{N}$ in leafy crops.

Leaf area. Table 6 shows the regression coefficients and the results of the statistical analysis.

Table 6. Exponential regression coefficients for the relationship between the leaf area and spectral indices

\begin{tabular}{ccccc}
\hline \multirow{2}{*}{$\begin{array}{c}\text { Period } \\
\text { evaluated }\end{array}$} & \multirow{2}{*}{$\begin{array}{c}\text { Spectral } \\
\text { index }\end{array}$} & \multicolumn{2}{c}{$\begin{array}{c}\text { Exponential regression } \\
\text { coefficient }\end{array}$} & \multirow{2}{*}{ SE } \\
\cline { 3 - 4 } & & $\mathrm{a}$ & $\mathrm{b}$ & \\
\hline 1 to 42 & $\mathrm{NGRDI}^{* *}$ & 1.2705 & 2.4701 & 0.06 \\
DAT & ExG** $^{* *}$ & 2.6704 & 2.1802 & 0.07 \\
22 to 42 & $g^{* *}$ & 4.1901 & 1.8506 & 0.07 \\
\cline { 2 - 4 } DAT & $\mathrm{NGRI}^{* *}$ & 1.5974 & 1.0563 & 0.08 \\
& ExG** $^{* *}$ & 1.2445 & 1.4357 & 0.06 \\
& $g^{* *}$ & 2.1352 & 1.0406 & 0.05 \\
\hline
\end{tabular}

Explanation of acronyms in Table $1 ; * *$ - high significant correlation between the variables $(P \leq 0.01)$

The indices NGRDI $(r=0.94, \mathrm{RMSE}=0.05)$, $\mathrm{ExG}(r=0.95, \mathrm{RMSE}=0.04)$ and $g(r=0.96, \mathrm{RMSE}=$ 0.03 ) showed best fit to an exponential model to estimate leaf area (Fig. 5).

This mathematical model is different from the one reported by Campillo et al. (2010) for the $g$ index, because they found a better fit to a linear model $(r \geq 0.92)$ in tomato. Besides, Horgan et al. (2015) and Beniaich et al. (2019) reported values with fit to linear models between leaf area and NGRDI in sweet pepper $(r=0.83)$ and basil $(r=0.85)$, respectively.

As is well known, the biomass can be used as a predictor of leaf area, especially in the early stages of crop growth. Studies in onion (Ballesteros et al., 2018) and tomato (Sun, Wang, 2019) report high correlations ( $r$ $\geq 0.87$ ) between the $g$ spectral index and leaf area; this is attributed to the growth rate of the crop. Furthermore, Hunt et al. (2013) found that the NGRDI is highly correlated with the amount of biomass in maize and soybean crops, especially in early stages, but tends to become saturated as the crop develops. Therefore, NGRDI can be useful in short-cycle plants such as leafy vegetables.

In the early stages of lettuce cultivation, the growth rate of leaf area is lower than in the later stages; therefore, the relationship with the indices with this parameter is not linear. Besides, results of our experiment show better fit to the exponential model in the last 21 days of the crop. This can be explained, because in early stages the RGB camera has spatial limitation to detect

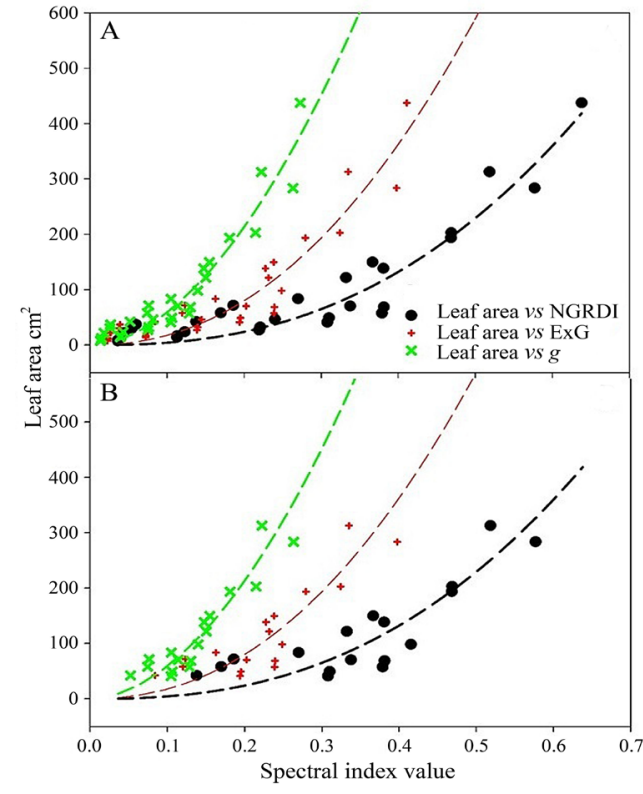

Explanation of acronyms in Table 1

Figure 5. Correlation between the concentration of leaf area and spectral indices (NGRDI, ExG and $g$ ) at 42 DAT (A) and the last 21 DAT (B)

leaf area in small leaves, this limitation is reduced as the crop grows. Therefore, the efficiency of this tool using the spectral indices derived from RGB digital images depends on the phenology and plant growth habit.

\section{Conclusions}

1. The normalized green-red difference index (NGRDI) had the highest correlation coefficient with the values of $\mathrm{Chl}(r=0.95)$ and $\mathrm{N}(r=0.93)$. Besides, the excess green $(\mathrm{ExG})$ index obtained the highest correlation with leaf area $(r=0.92)$. These indices highlight the spectral response in the green and red regions and are more accurate than the indices using the blue band.

2. Romaine lettuce has an accelerated leaf growth in the last stages of its vegetative cycle. In this study, the values of NGRDI, ExG and green channel $(g)$ indices compared to leaf area are better adjusted to an exponential model. So, the use of this technique requires considering the type of crop and its phenology or growth habit.

3 . The accuracy of the spectral indices derived from RGB (red, green and blue) digital images for estimating N, Chl status and leaf area increases in the later stages of romaine lettuce cultivation. It is because in the early stages of growth the leaves are small in size, which is a spatial limitation for detection by the RGB camera.

4. The use of spectral indices derived from RGB digital images is useful and accurate for the estimation of $\mathrm{N}$, Chl status and leaf area during the production of lettuce. It could be a low-cost alternative to destructive methods, and it can be part of a combined system with portable meters (SPAD, atLEAF and others) for real-time monitoring of vegetables grown in a crop factory.

\section{Acknowledgments}

The first author is grateful to the National Council of Science and Technology (CONACYT, Mexico) for the scholarship No. 473176 awarded for graduate studies.

Received 21042020

Accepted 29092020 


\section{References}

Ali M. M., Al-ani A., Eamus D., Tan D. K. Y. 2013, Al algorithm based on the RGB colour model to estimate plant chlorophyll and nitrogen contents. International Conference on Sustainable Environment and Agriculture, 57 (2013): 52-60.

Álvarez-Bermejo J. A., Giagnocavo C., Li M., Morales E. C., Santos D. P. M., Yang X. T. 2017. Image processing methods to evaluate tomato and zucchini damage in postharvest stages. International Journal of Agricultural and Biological Engineering, 10 (5): 126-133. https://doi.org/10.25165/j.ijabe.20171005.3087

Ballesteros K., Urtega J. F., Hernandez D., Moreno M. A 2018. Onion biomass monitoring using UAV-based RGB imaging. Precision A griculture, 19 (5): 840-857. https://doi.org/10.1007/s11119-018-9560-y

Baresel J. Y., Kischbeck P., Hu Y., Kipp S., Hu Y., Barmeier G., Mistele B. 2017. Use of a digital camera as alternative method for non-destructive detection of the leaf chlorophyll content and the nitrogen nutrition status in wheat Computers and Flectronics in Agriculture, 140: 25-33. https://doi.org/10.1016/j.compag.2017.05.032

Benıaich A., Naves silva M. L., Pomar Avaios F. A., de Menezes M. D., Moreira Cândido B. 2019. Determination of vegetation cover index under different soil management systems of cover plants by using an unmanned aerial vehicle with an onboard digital photographic camera. Semina Ciências Agrárias, 40 (1). 49 https://doi.org/10.5433/1679-0359.2019v40n1p49

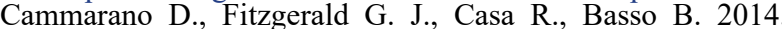
Assessing the robustness of vegetation indices to estimate wheat $\mathrm{N}$ in Mediterranean environments Remnte Sensing, 6 (4): 2827-2844. https://doi.org/10.3390/rs6042827

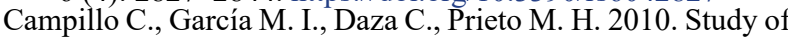
a non-destructive method for estimating the leaf area index in vegetable crops using digital images. HortScience, 45 $(10) \cdot 1459-1463$ https://doi.org/10.21273/HORTSCI.45.10.1459

Chung Y. S., Choi S. C., Silva K. K., Kang J. W., Eom J. H., Kim C. 2017. Case study: estimation of sorghum biomass using digital image analysis with Canopeo. Biomass and Rinenergy, 105. ?07-710 https://doi.org/10.1016/j.biombioe.2017.06.027

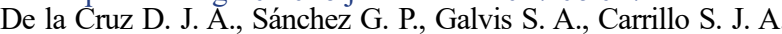
2011. Spectral indexes in sweet pepper for diagnosis of nitrogen nutrient status. Terra Latinoamericana, 29 (3): $259-265$.

Elazab A., Ordóñez R. A., Savin R., Slafer G. A., Araus J. L. 2016. Detecting interactive effects of $\mathrm{N}$ fertilization and heat stress on maize productivity by remote sensing techniques. Furnnean Inurnal of A gronomy 73: 11-24. https://doi.org/10.1016/j.eja.2015.11.010

Elsayed S., Barmeie G., Schmidhaiter U. 2018. Passive reflectance sensing and digital image analysis allows for assessing the biomass and nitrogen status of wheat in early and late tillering stages Frontiers in Plant Science, 9: 1478 https://doi.org/10.3389/fpls.2018.01478

Fallovo Č., Kouphaei Y., Kea E., Battisteiii A., Colla G. 2009 Nutrient solution concentration and growing season affect yield and quality of Lactuca sativa $\mathrm{L}$. var. acephala in floating raft culture. Journal of the Science of Food and Agriculture, $89(10) \cdot 1687-1689$ https://doi.org/10̀.10́02/jsfa.3641

Grenzdorffer $\overline{\mathrm{U}}$. J. Zui 4 . Crop height determination with UAS point clouds. ISPRS Technical Commission I Symposium, n $135-140$ https://doi.org/10.5194/isprsarchives-XL-1-135-2014

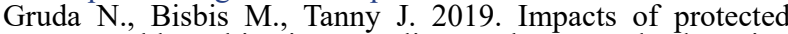
vegetable cultivation on climate change and adaptation strategies for cleaner production - a review. Journal of Cleaner Production 205. 324-330 https://doi.org/10.1016/j.jclepro.2019.03.295

Horgan $\bar{G}$. $\overline{\text { W. }}$., Song $\bar{Y}$., Ǵlasbey $\bar{C}$. A., van der Heijden G. W. A. M., Polder G., Dieleman J. A., Van Eeuwijk F. A. 2015. Automated estimation of leaf area development in sweet pepper plants from image analysis. Functional Plant Rinlogy 4) (5) $486-49$ ? https://doi.org/10.1071/FP14070

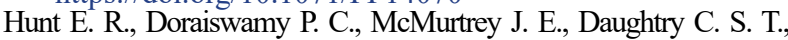
Perry E. M., Akhmedov B. 2013. A visible band index for remote sensing leaf chlorophyll content at the canopy scale. International Journal of Applied Earth Observation and Geninformation, $7.1 \cdot 103-11$ ? https://doi.org/10.1016/j.jag.2012.07.020
Jannoura R., Brinkmann K., Uteau D., Bruns C., Joergensen R. G. 2015. Monitoring of crop biomass using true colour aerial photographs taken from a remote controlled hexacopter. Binsystems Fngineering. 129: 341-351 https://doi.org/10.1016/j.biosystemseng.2014.11.007

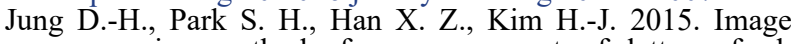
processing methods for measurement of lettuce fresh weight . Iournal of Binsystems Fngineering 40 (1): 89-93. https://doi.org/10.5307/JBE.2015.40.1.089

Kalra Y. $\bar{Y} \bar{y} \bar{y} \bar{T}$. Handibook of Keference Miethods for Plant Analvsis. IJSA $88 \mathrm{n}$

https://doi.org/10.1201/9781420049398

Konstantopoulou E., Kapotis G̈., Salachas G̈., Petropoulos S.A., Chatzieustratiou E., Karapanos I. C., Passam H. C. 2012. Effect of nitrogen application on growth parameters, yield and leaf nitrate content of greenhouse lettuce cultivated during three seasons Inurnal of Plant Nutrition $35(8)$. 1246-1254. https://doi.org/10.1080/01904167.2012.676135

Lee K.-J., Lee B.-W. 2U13. Estimation of rice growth and nitrogen nutrition status using color digital camera image analvsis Furnnean Inurnal of A ornnomv, 48: 57-65. https://doi.org/10.1016/j.eja.2013̆.02.011

Lin K., Chen J., Si H., Wu J. ZUI3. A review on computer vision technologies applied in greenhouse plant stress detection. Communications in Computer and Information Science, $362 \cdot 197-700$ https://doi.org/10.1007/978-3-642-37149-3 23

Liu S., Li L., Gao W., Lhang Y., Liu Y., Wang S., Lu J. 2018. Diagnosis of nitrogen status in winter oilseed rape (Brassica napus L.) using in-situ hyperspectral data and unmanned aerial vehicle (UAV) multispectral images. Computers and Flectronics in Agriculture, 151: 185-195. https://doi. org/10.1016/j.compag.2018.05.026

Mackinney G. ígil. Absorption of light by chlorophyll solutions. Journal of Biological Chemistry, 140 (2): 315-322.

Mao H., Gao H., Zhang X., Kumi F. 2015. Nondestructive measurement of total nitrogen in lettuce by integrating spectroscony and computer vision. Scientia Horticulturae, 184: 1-7. https://doi.org/10.1016/j.scienta.2014.12.027

Mercado-Luna A., Kico-Garcia E., Lara-Ḧerrera, A., SotoZarazúa G., Ocampo-Velásquez R., Guevara-González R., Herrera-Ruiz G., Torres-Pacheco I. 2010. Nitrogen determination on tomato (Lycopersicon esculentum Mill.) seedlings by color image analysis (RGB). African Journal of Agricultural Research, 9 (33): 5326-5332.

Meyer G. E., Neto J. C. 2008. Verification of color vegetation indices for automated crop imaging applications. Computers and Flectronics in Agriculture, 63 (?). 287-793. https://doi.org/10.1016/j.compag.2008.03.009

Munoz-Huerta K. F., Guevara-Gonzalez K. G., ContrerasMedina L. M., Torres-Pacheco I., Prado-Olivarez J., Ocampo-Velazquez R. V. 2013. A review of methods for sensing the nitrogen status in plants: advantages, disadvantages and recent advances Sensors (Switzerland) 13 (8): 10823-10843. https://doi.org/10.3390/s130810823

Parks S. E., Irving D. E., Miliham P. J. 20I2. A critical evaluation of on-farm rapid tests for measuring nitrate in leafy vegetahles. Scientia Horticulturae, 134: 1-6. https://doi.org/10.1016/j.scienta.2011.10.015

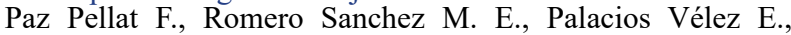
Bolaños González M., Aldrete A., Valdez Lazalde J. R. 2015. Scopes and limitations of spectral vegetation indices: analysis of broad band indices. Terra Latinoamericana, 33 (1): 27-49 (in Spanish).

Prey L., von Bloh M., Schmidhalter U. 2018. Evaluating RGB imaging and multispectral active and hyperspectral passive sensing for assessing early plant vigor in winter wheat. Sensors. 18 (9): 2931 https://doi.org/10.3390/s18092931

Rasmussen J̄., N̄takos G̈., Nieisen J., Sivensgaard J., Poulsen R. N., Christensen S. 2016. Are vegetation indices derived from consumer-grade cameras mounted on UAVs sufficiently reliable for assessing experimental plots? European Journal of Agronomy, 74: 75-92 https://doi.org/10.1016/j.eja.2015.11.026

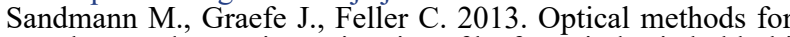
the non-destructive estimation of leaf area index in kohlrabi and lettuce Scientia Horticulturae 156.113-120. https://doi.org/10.1016/j.scienta.2013.04.003

Sandmeier S. K. ZUUU. Acquisition of bidirectional reflectance factor data with field goniometers. Remote Sensing of Environment, 73 (3): 257-269. https://doi.org/10.10́16/S0034-4257(00)00102-4 
Santamaria P., Elia A., Serio F. 2002. Effect of solution nitrogen concentration on yield, leaf element content, and water and nitrogen use efficiency of three hydroponically-grown rocket salad genotynes. Journal of Plant Nutrition, 25 (2): 245-258. https://doi.org/10.1081/PLN-100108833

Steiner A. A. 1984. The universal nutrient solution. Proceedings of the $6^{\text {th }}$ International Congress on Soilless Culture. Wageningen, The Netherlands, p. 633-649.

Sun G. X., Li Y. B., Wang X. C., Hu G. Y., Wang X., Zhang Y. 2016. Image segmentation algorithm for greenhouse cucumber canopy under various natural lighting conditions. International Journal of Agricultural and Biological Engineering. 9 (3): 130-138. https://doi.org/10.3965/j.ijabe.20160903.2102

Sun G., Wang X. 2019. Three-dimensional point cloud reconstruction and morphology measurement method for greenhouse plants based on the Kinect sensor selfcalibration. Agronomy, 9 (10): 203-263 https://doi.org/10.3390/agronomy9100596

Taiz L., Zeiger E., Moller I. M., Murphy A. 2014. Plant Physiology and Development $\left(6^{\text {th }}\right.$ ed.). Oxford University Press, $761 \mathrm{p}$.

Usha K., Singh B. 2013. Potential applications of remote sensing in horticulture - a review. Scientia Horticulturae, 153: 71-83. https://doi.org/10.1016/j.scienta.2013.01.008

Vollmann J., Walter H., Sato T., Schweiger P. 2011. Digital image analysis and chlorophyll metering for phenotyping the effects of nodulation in soybean. Computers and Electronics in Agriculture. 75 (1): 190-195. https://doi.org/10.1016/j.compag.2010.11.003

WettsteinD. 1957.Chlorophyll-letaleunddersubmikroskopische Formwechsel der Plastiden. Experimental Cell Research, 12 (3): 427-506 (in German).

https://doi.org/10.1016/0014-4827(57)90165-9
Xue L., Yang L. 2008. Recommendations for nitrogen fertilizer topdressing rates in rice using canopy reflectance spectra. Biosystems Engineering. 100 (4): 524-534 https://doi.org/10.1016/j.biosystemseng.2008.05.005

Yadav S. P., Ibaraki Y., Gupta S. D. 2010. Estimation of the chlorophyll content of micropropagated potato plants using RGB based image analysis. Plant Cell, Tissue and Organ Culture. 100 (2): 183-188.

https://doi.org/10.1007/s11240-009-9635-6

Yang M., Hassan M. A., Xu K., Zheng C., Rasheed A., Zhang Y., Jin X., Xia X., Xiao Y. He Z. 2020. Assessment of water and nitrogen use efficiencies through UAV-based multispectral phenotyping in winter wheat. Frontiers in Plant Science, 11: 927. https://doi.org/10.3389/fpls.2020.00927

Yuzhu H. 2011. Nitrogen determination in pepper (Capsicum frutescens L.) plants by color image analysis (RGB). African Journal of Biotechnologv. 10 (77): 1003-1023. https://doi.org/10.5897/AJB11.1974

Zandvakili O. R., Barker A. V., Hashemi M., Etemadi F., Autio W. R., Weis S. 2019. Growth and nutrient and nitrate accumulation of lettuce under different regimes of nitrogen fertilization. Journal of Plant Nutrition. 42 (14): 1575-1593. https://doi.org/10.1080/01904167.2019.1617313

Zheng H., Cheng T., Li D., Zhou X., Yao X., Tian Y., Zhu Y. 2018. Evaluation of RGB, color-infrared and multispectral images acquired from unmanned aerial systems for the estimation of nitrogen accumulation in rice. Remote Sensing, 10 (6): 824. https://doi.org/10.3390/rs10060824

Zhou W., Lv T., Hu Y., Liu W., Bi Q., Jin C., Lin X. 2020. Effect of nitrogen limitation on antioxidant qualities is highly associated with genotypes of lettuce (Lactuca sativa L.). Pedosnhere, 30 (3): 414-425. https://doi.org/10.1016/S1002-0160(19)60833-7

\title{
Azoto ir chlorofilo kiekis sẻjamųjų salotų lapuose, nustatytas naudojant raudonai žaliai mèlyno (RŽM) skaitmeninio vaizdo spektrinius indeksus
}

\author{
R. O. Mendoza-Tafolla ${ }^{1}$, R. E. Ontiveros-Capurata ${ }^{2}$, P. Juarez-Lopez ${ }^{1}$, I. Alia-Tejacal ${ }^{1}$, \\ V. Lopez-Martinez ${ }^{1}$, O. Ruiz-Alvarez ${ }^{3}$ \\ ${ }^{1}$ Autonominio Morelos valstijos universiteto Žemés ūkio mokslu fakultetas, Meksika \\ ${ }^{2}$ Nacionalinès mokslo ir technologijų tarybos Meksiko vandens technologijos institutas, Meksika \\ ${ }^{3}$ Nacionalinio miškų, žemès ūkio ir gyvulininkystės tyrimų instituto (INIFAP) \\ Nacionalinè nuotolinio stebejjimo ir modeliavimo laboratorija, Meksika
}

\section{Santrauka}

Destruktyvūs augalų mitybos įvertinimo metodai yra tikslūs ir standartizuoti, tačiau brangūs ir apriboti erdvinès skalès. Nedestruktyvių metodų, pavyzdžiui, skaitmeninio vaizdo naudojimas, duoda greitus ir patikimus rezultatus in situ. Tačiau yra nedaug informacijos apie šių nedestruktyvių metodų naudojimą tiriant lapines daržoves. Tyrimo metu buvo vertinta azoto $(\mathrm{N})$ ir chlorofilo (Chl) koncentracija sejjamujų salotų lapuose naudojant spektrinius indeksus, gautus iš raudonai žaliai mèlyno (RŽM) skaitmeninio vaizdo. Salotos augintos plastikiniuose šiltnaminiuose tuneliuose modifikuotame Steinerio tirpale ir laistytos penkių koncentracijų N tirpalu: $0,4,8$, 12 ir $16 \mathrm{mEq} \mathrm{L}^{-1} \mathrm{NO}_{3}-\mathrm{N}$ (atitinkamai 0, 248, 496 ir $744 \mathrm{mg} \mathrm{L}^{-1}$ ). Laistant $16 \mathrm{mEq} \mathrm{L}^{-1} \mathrm{NO}_{3}-\mathrm{N}$, salotų augimas buvo didžiausias 42 dieną po persodinimo. Augalų skaitmeniniai vaizdai kas savaitę buvo fotografuojami RŽM fotoaparatu ir apdoroti, kad būtų gauta mastelio matrica ir dvylika augalų spektrinių indeksų. Spektrinių indeksų koreliacijos analizè parodè, kad normalizuotas žaliai raudonos komponentès skirtumo indeksas, perteklinis žalios komponentès $(\mathrm{ExG})$ ir žaliojo kanalo $(\mathrm{g})$ indeksai sudare teigiamą tiesinę koreliaciją su $\mathrm{N}(r>0,93)$ ir Chl $(r>$ $0,93)$ kiekiu. Taip pat buvo nustatyta eksponentiné koreliacija su lapų plotu $(r>0,86)$, kuri po persodinimo praejjus 21 dienai buvo stipresnè dèl greitesnio lapų augimo vegetacijos metu.

Tyrimo duomenimis, RŽM skaitmeninio vaizdo taikymas yra nebrangus, nedestruktyvus, patikimas ir tikslus metodas, siekiant ịvertinti sejjamujų salotų N bei Chl koncentraciją ir lapų plotą augimo metu. Šis metodas galètų būti veiksminga alternatyva, kartu su nešiojamais chlorofilo matavimo prietaisais (SPAD) realiuoju laiku leidžianti stebèti salotų mitybinę būklę, ypač daržoves auginant pramoniniu būdu.

Reikšminiai žodžiai: Lactuca sativa var. longifolia, lapų plotas, nedestruktyvus metodas, azotas, chlorofilas, spektrinis indeksas. 